The Political Economy

of Tanzania 
This page intentionally left blank 


\section{The Political Economy of Tanzania}

Decline and Recovery

Michael F. Lofchie

\section{$\overline{\text { PENN }}$}

UNIVERSITY OF PENNSYLVANIA PRESS

PHILADELPHIA 
Copyright (c) 2014 University of Pennsylvania Press

All rights reserved. Except for brief quotations used for purposes of review or scholarly citation, none of this book may be reproduced in any form by any means without written permission from the publisher.

Published by

University of Pennsylvania Press

Philadelphia, Pennsylvania 19104-4112

www.upenn.edu/pennpress

Printed in the United States of America on acid-free paper

1098876554321

Library of Congress Cataloging-in-Publication Data

Lofchie, Michael F.

The political economy of Tanzania : decline and recovery / Michael F. Lofchie.

-1 st ed.

p. $\mathrm{cm}$.

Includes bibliographical references and index.

ISBN 978-0-8122-4590-5 (hardcover : alk. paper)

1. Economic development-Political aspects-Tanzania. 2. Tanzania-Economic policy. 3. Tanzania-Economic conditions-1964-4. Tanzania-Politics and government-1964- I. Title.

HC885.L6374 2014 
Between what matters and what seems to matter, how should the world we know judge wisely?

-E. C. Bentley, Trent's Last Case, Chapter 1 
This page intentionally left blank 
For Kelly and Hudson 
This page intentionally left blank 